\title{
Determining Bioecological and Biometric Properties of Freshwater Mussels (Unio crassus Philipsson, 1788)
}

\author{
Serpil Serdar*, Hazal Bulut, Melike Eden, Yusuf Özdemir \\ Ege University, Faculty of Fisheries, Bornova-İzmir, Turkey
}

Received: 25 March 2018

Accepted: 27 April 2018

\begin{abstract}
Population characteristics of Unio crassus, an endangered freshwater mussel in many countries, are very important. In this study, we have attempted to determine the environmental conditions of Aydın-Çine Creek and the biometric properties of U.crassus. The largest length during the study period was $92.50 \mathrm{~mm}$ in February, and the smallest length was $37.03 \mathrm{~mm}$ in April. In addition, the heaviest individual was found to be $124.15 \mathrm{~g}$ in February, while the smallest individual was $6.69 \mathrm{~g}$ in April. It was found that 141 individuals were found in a group of 70.0-79.99 $\mathrm{mm}$ at maximum in the distribution frequency of U.crassus in Çine Creek. The water temperature was measured at $9.8-24.0^{\circ} \mathrm{C}$, and oxygen value was $6.0-10.4 \mathrm{mg} / \mathrm{L}$ during the study. In the current environmental conditions in Çine Creek, various sizes and population development of U.crassus have been identified.
\end{abstract}

Keywords: Unio crassus, thick-shelled river mussel, biometric measurements, Çine Creek, Turkey

\section{Introduction}

Freshwater mussels have an important role in the ecological system because of their filter feeding organism and its interesting life cycle [1]. Some freshwater mussel species are economically important as they have potential for production, consumption, and processing. Mussels that have nacreous shell produce pearl and have a particularly high market value [2-3]. The numbers of some freshwater mussel species have decreased day by day and have even become in danger of extinction due to pollution, drought, coastal arrangements, insensible fishing, and a low number of host fish in the environment [4-5].

*e-mail: serpil.serdar@ege.edu.tr,
Despite the fact that Unio crassus has spread to many parts of the world and has produced a high population (over 700 individuals $/ \mathrm{m}^{2}$ ), the number of freshwater mussels in Europe has been greatly reduced in the last 40-50 years [6-8]. Only the population in the Baltic States and in the European side of Russia is in relatively good condition. However, the situation of the population in Greece and Turkey is not yet known [8]. U.crassus is a sensitive organism of unfavorable environmental conditions, closely related to the need for specific ecological requirements at different stages of life, and therefore the conditions of environment to be optimal is directly related with the ability to complete its life cycle [7]. It has been reported that $U$. crassus has lived up to 75 years and some shells even have 90 growth rings [9]. When the growth and survival ages of U. crassus are compared, it is reported that slow-growing 
individuals have longer lives than fast-growing individuals [10-11].

It is determined that more information is required due to lack of knowledge about the populations' structure of Unio crassus where it is distributed among other countries. Studies in Turkey have focused on growth and some biological properties of freshwater mussels such as Unio pictorum and Unio tumidus [12-13], there has been no study related to U. crassus's population situation. For this reason, in order to determine the population status of $U$. crassus in Aydin Çine Creek, biometrics measurements of mussels were taken, length frequency was examined, and relations between biometric measurements and changes of environmental parameters were determined.

\section{Materials and Methods}

\section{Study Area}

Çine Creek is a branch of the Büyük Menderes River, which is one of the longest rivers of Western Anatolia. It is approximately $119 \mathrm{~km}$ long and is within the borders of Aydın [14]. Çine Creek $\left(37^{\circ} 45^{\prime} 51^{\prime \prime} \mathrm{N}\right.$, $27^{\circ} 49^{\prime} 59^{\prime \prime} \mathrm{E}$ ) was selected to study the population status of Unio crassus (thick-shelled river mussel). Samples were collected by hand from a maximum $70 \mathrm{~cm}$ depth and sandy bottom (Fig. 1).

\section{Environmental Factors}

Water samples were taken from the study area on a monthly basis and the water parameters in the area where the mussels were distributed were followed. The water temperature was measured during sampling with an alcohol thermometer $\left(-10\right.$ to $\left.100 \quad 0.5^{\circ} \mathrm{C}\right)$. Water samples were taken to determine the amount of oxygen and were examined in laboratory according to the Winkler method. Water samples were taken to determine total particulate matter (TPM), particulate inorganic matter (PIM), particulate organic matter (POM), and chlorophyll-a, and were filtrated with GF/C filter paper in the laboratory. Analyses were made according to the method developed by Strickland and Parsons [15].

\section{Sampling and Biometric Measurements}

The study was conducted monthly between September 2012 and August 2013. In total, 30 live individuals of $U$. crassus were collected from Çine Creek every month and their biometric measurements were taken. In order not to measure the same mussels, those collected were taken away from the current station. Shell length, width, and thickness measurements were made with the aid of a digital caliper (IP 66-Mitutoyo Absolute) and weights were measured with digital scales ( $\pm 0.01 \mathrm{~g})$.

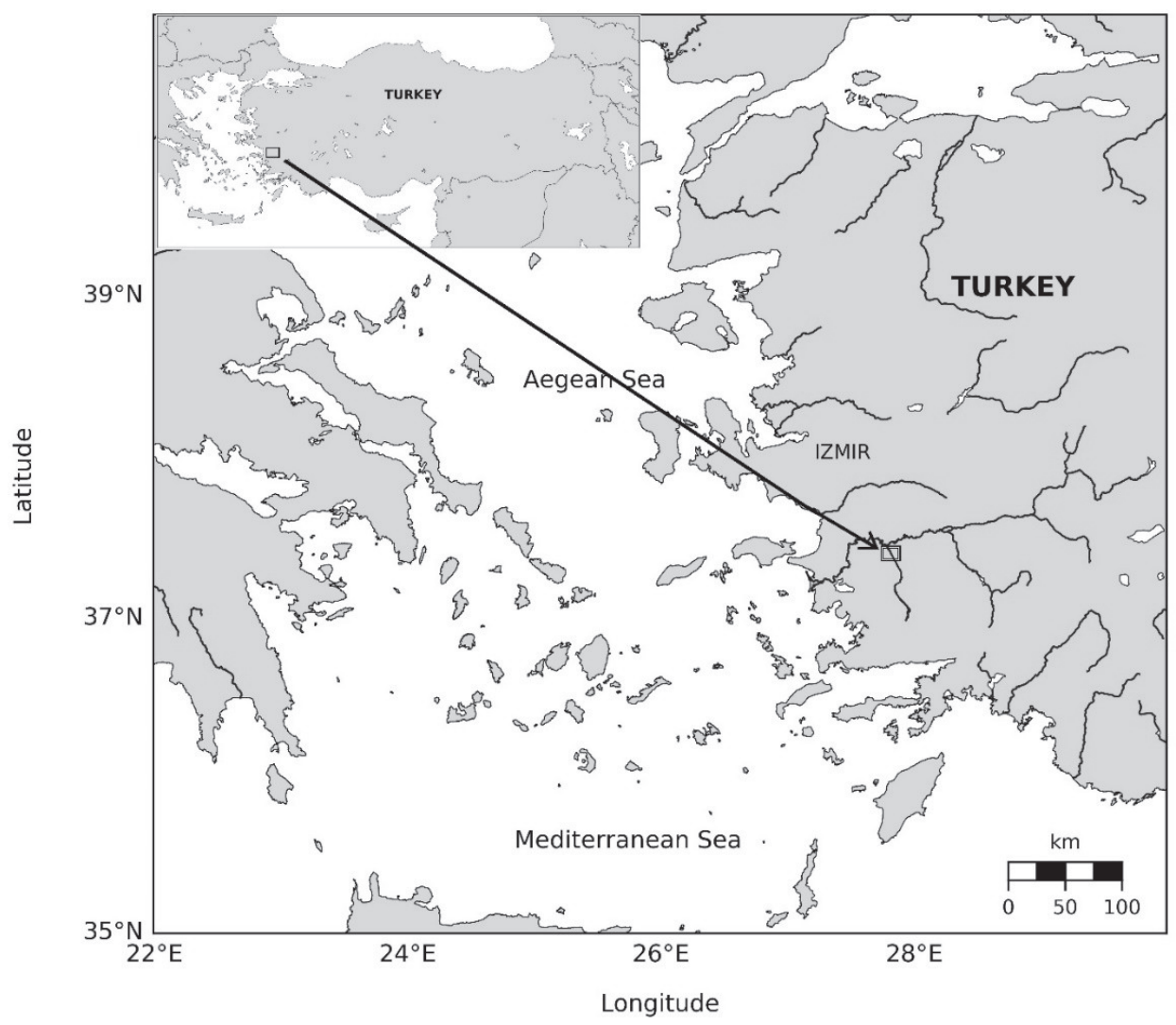

Fig. 1. Map of the study area. 


\section{Data Analysis}

Shell length was measured from the widest point in the anterior-posterior axis line, and thickness is the measurement taken from the highest point when two shells come together.

The $\mathrm{W}=\mathrm{aL}^{\mathrm{b}}$ equation was used to determine the relationship between shell length-weight, weight-width, weight-thickness, shell length-width, and shell lengththickness of freshwater mussels [16]. "W" represents total weight, "L" represents shell length (anteriorposterior axis), and "a" and "b" coefficients represent growth parameters. If the value of $b$ is equal to 3 , it is defined as isometry, and negative allometry is defined when $b<3$ and positive allometry is defined when $b>3$. Also, the value of " $r$ " (correlation coefficient) is calculated to determine the force between the parameters. Microsoft Excel Office 2010 was used to examine the biometric measurements and to determine the relationships between the dimensions.

\section{Results}

\section{Environmental Parameters}

The water temperature ranged from $9.8^{\circ} \mathrm{C}$ to $24.0^{\circ} \mathrm{C}$ during the study, while the oxygen level was measured between $6.0 \mathrm{mg} / \mathrm{L}$ and $10.4 \mathrm{mg} / \mathrm{L}$ (Fig. 2). The highest amount of chlorophyll-a was detected in

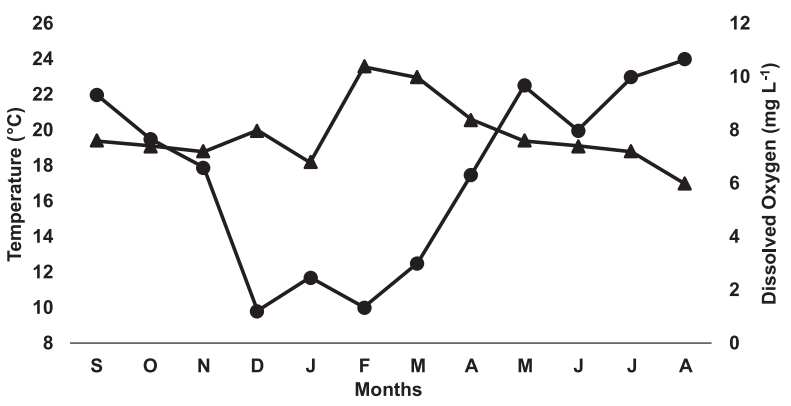

Fig. 2. Variation of water temperature and oxygen values.

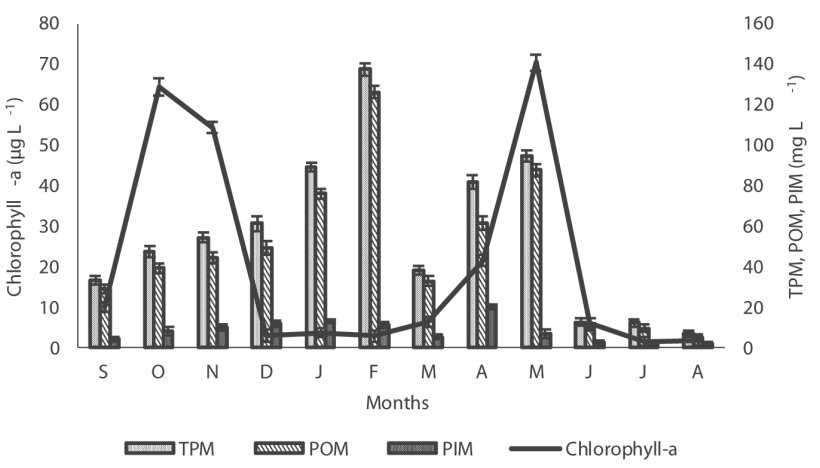

Fig. 3. Chlorophyll-a, TPM, POM, and PIM levels.
May $(70.48 \mu \mathrm{g} / \mathrm{L})$ and the lowest in July $(1.58 \mu \mathrm{g} / \mathrm{l})$. The highest and the lowest values of total particulate matter (TPM) were determined in October $(123.2 \mathrm{mg} / \mathrm{L})$ and August $(7 \mathrm{mg} / \mathrm{L})$. The highest and the lowest POM were found in February and August as $126.16 \mathrm{mg} / \mathrm{L}$ in and $5 \mathrm{mg} / \mathrm{l}$, respectively. PIM concentration was highest in April $(20.3 \mathrm{mg} / \mathrm{L})$ and lowest in August $(2 \mathrm{mg} / \mathrm{L})$ (Fig. 3).

\section{Biometric Properties}

The largest average length of freshwater mussels was measured in September as $71.00 \pm 1.99 \mathrm{~mm}$, and the smallest average length was measured in April as $62.51 \pm 2.10$ (Table 1). The largest length during the study period was in February as $92.50 \mathrm{~mm}$ and the smallest length was in April as $37.03 \mathrm{~mm}$ (Table 1).

The highest average width was in September as $39.52 \pm 1.03 \mathrm{~mm}$, while the lowest average width was in April as $35.08 \pm 1.07 \mathrm{~mm}$. During the study, the largest individual was measured in June as $51.18 \mathrm{~mm}$, while the minimum width was measured in October as $21.28 \mathrm{~mm}$ (Table 1).

The largest average thickness was found in September as $26.48 \pm 0.77 \mathrm{~mm}$, and the smallest average thickness was found in April as $22.99 \pm 0.76 \mathrm{~mm}$. The thickest individual was measured in February as $36.23 \mathrm{~mm}$ and the minimum thickness was found in April as $13.37 \mathrm{~mm}$ (Table 1).

The highest average weight was in September as $48.82 \pm 3.41 \mathrm{~g}$ and the lowest average weight was in April as $33.73 \pm 2.86 \mathrm{~g}$. The highest weight was found in February as $124.15 \mathrm{~g}$, while the smallest individual was in April as $6.69 \mathrm{~g}$ (Table 1).

When the averages of the biometric measurements of the freshwater mussels collected throughout the year were calculated, the average shell length was $71.75 \pm 7.63 \mathrm{~mm}$, average width $39.95 \pm 4.20 \mathrm{~mm}$, average thickness $26.90 \pm 3.74 \mathrm{~mm}$, and average weight $48.41 \pm 16.63 \mathrm{~g}$ (Table 1).

For the frequency distribution of the individuals measured, we found that the maximum number of individuals is in the group of 70.0-79.99 $\mathrm{mm}$, with 141 individuals. Three individuals were found in the longest-length group (90.0-99.99 mm), and five individuals were found in the smallest length group (30.00-39.99 mm) (Fig. 4).

\section{Relationship between Biometric Measures}

When all biometric measurements were compared, we concluded that there was negative allometric relationship in all cases (Table 2). The lowest correlation coefficient (r) in the study was found to be between shell length and shell width (0.93). The highest $r$ value (0.97) was calculated between shell length and weight, and shell length and width, and a strong correlation was found between these measures (Table 2). 
Table 1. Biometric measurements of $U$. crassus.

\begin{tabular}{|c|c|c|c|c|c|}
\hline & & $\mathrm{N}$ & $\begin{array}{l}\text { Mean } \\
X \pm \text { SE }\end{array}$ & Min & Max \\
\hline \multirow{4}{*}{ September } & Shell Length (mm) & 30 & $71.00 \pm 1.99$ & 42.42 & 86.16 \\
\hline & Shell Width (mm) & 30 & $39.52 \pm 1.03$ & 25.46 & 46.75 \\
\hline & Shell Height (mm) & 30 & $26.48 \pm 0.77$ & 16.95 & 32.29 \\
\hline & Weight (g) & 30 & $48.82 \pm 3.41$ & 6.98 & 82.75 \\
\hline \multirow{4}{*}{ October } & Shell Length (mm) & 30 & $65.81 \pm 1,90$ & 37.52 & 79.68 \\
\hline & Shell Width (mm) & 30 & $36.84 \pm 1,05$ & 21.28 & 43.5 \\
\hline & Shell Height (mm) & 30 & $25.32 \pm 0.75$ & 15.40 & 30.11 \\
\hline & Weight (g) & 30 & $40.38 \pm 2.75$ & 7.29 & 60.36 \\
\hline \multirow{4}{*}{ November } & Shell Length (mm) & 30 & $67.21 \pm 1.96$ & 61.91 & 84.43 \\
\hline & Shell Width (mm) & 30 & $37.73 \pm 1.08$ & 34.57 & 48.19 \\
\hline & Shell Height (mm) & 30 & $25.25 \pm 0.72$ & 16.90 & 32.10 \\
\hline & Weight (g) & 30 & $41.50 \pm 3.12$ & 9.64 & 73.50 \\
\hline \multirow{4}{*}{ December } & Shell Length (mm) & 30 & $68.74 \pm 1.98$ & 63.83 & 85.01 \\
\hline & Shell Width (mm) & 30 & $38.31 \pm 1.16$ & 21.38 & 47.12 \\
\hline & Shell Height (mm) & 30 & $26.20 \pm 0.83$ & 13.87 & 33.13 \\
\hline & Weight (g) & 30 & $46.48 \pm 3.46$ & 7.34 & 84.79 \\
\hline \multirow{4}{*}{ January } & Shell Length (mm) & 30 & $67.80 \pm 1.76$ & 39.95 & 75.55 \\
\hline & Shell Width (mm) & 30 & $37.85 \pm 0.92$ & 22.87 & 42.30 \\
\hline & Shell Height (mm) & 30 & $24.66 \pm 0.63$ & 14.42 & 28.11 \\
\hline & Weight (g) & 30 & $40.00 \pm 2.15$ & 8.99 & 48.66 \\
\hline \multirow{4}{*}{ February } & Shell Length (mm) & 30 & $68.41 \pm 2.45$ & 40.59 & 92.52 \\
\hline & Shell Width (mm) & 30 & $38.25 \pm 1.30$ & 22.89 & 50.53 \\
\hline & Shell Height (mm) & 30 & $25.70 \pm 0.96$ & 15.09 & 36.23 \\
\hline & Weight (g) & 30 & $46.99 \pm 5.12$ & 8.97 & 124.15 \\
\hline \multirow{4}{*}{ March } & Shell Length (mm) & 30 & $68.33 \pm 1.86$ & 40.88 & 80.36 \\
\hline & Shell Width (mm) & 30 & $36.03 \pm 1.00$ & 24.58 & 43.91 \\
\hline & Shell Height (mm) & 30 & $23.84 \pm 0.70$ & 15.13 & 30.22 \\
\hline & Weight (g) & 30 & $37.61 \pm 2.90$ & 10.18 & 64.14 \\
\hline \multirow{4}{*}{ April } & Shell Length (mm) & 30 & $62.51 \pm 2.10$ & 37.03 & 84.3 \\
\hline & Shell Width (mm) & 30 & $35.08 \pm 1.07$ & 21.34 & 45.80 \\
\hline & Shell Height (mm) & 30 & $22.99 \pm 0.76$ & 13.37 & 30.37 \\
\hline & Weight (g) & 30 & $33.73 \pm 2.86$ & 6.69 & 69.09 \\
\hline \multirow{4}{*}{ May } & Shell Length (mm) & 30 & $68.35 \pm 2.26$ & 41.30 & 85.38 \\
\hline & Shell Width (mm) & 30 & $37.96 \pm 1.25$ & 23.03 & 49.18 \\
\hline & Shell Height (mm) & 30 & $25.67 \pm 0.90$ & 14.52 & 32.92 \\
\hline & Weight (g) & 30 & $43.40 \pm 3.81$ & 8.73 & 79.7 \\
\hline \multirow{4}{*}{ June } & Shell Length (mm) & 30 & $69.13 \pm 2.14$ & 41.61 & 91.28 \\
\hline & Shell Width (mm) & 30 & $38.05 \pm 1.15$ & 23.10 & 51.18 \\
\hline & Shell Height (mm) & 30 & $25.36 \pm 0.75$ & 14.98 & 33.5 \\
\hline & Weight (g) & 30 & $43.68 \pm 3.69$ & 9.08 & 93.62 \\
\hline
\end{tabular}


Table 1. Continued

\begin{tabular}{|c|c|c|c|c|c|}
\hline \multirow{4}{*}{ July } & Shell Length $(\mathrm{mm})$ & 30 & $69.78 \pm 1.93$ & 41.93 & 81.38 \\
\cline { 2 - 6 } & Shell Width $(\mathrm{mm})$ & 30 & $39.40 \pm 1.01$ & 27.07 & 46.19 \\
\cline { 2 - 6 } & Shell Height $(\mathrm{mm})$ & 30 & $26.15 \pm 0.77$ & 16.58 & 32.42 \\
\cline { 2 - 6 } & Weight $(\mathrm{g})$ & 30 & $46.29 \pm 3.19$ & 10.80 & 73.38 \\
\hline \multirow{5}{*}{ August } & Shell Length $(\mathrm{mm})$ & 30 & $70.28 \pm 2.06$ & 42.31 & 86.45 \\
\cline { 2 - 6 } & Shell Width $(\mathrm{mm})$ & 30 & $39.11 \pm 1.17$ & 23.63 & 50.00 \\
\cline { 2 - 6 } & Shell Height $(\mathrm{mm})$ & 30 & $25.80 \pm 0.86$ & 15.06 & 33.28 \\
\cline { 2 - 6 } & Weight $(\mathrm{g})$ & 30 & $45.27 \pm 3.52$ & 9.08 & 76.38 \\
\hline \multirow{5}{*}{ All year } & Shell Length $(\mathrm{mm})$ & 360 & $71.75 \pm 7.63$ & 37.03 & 92.50 \\
\cline { 2 - 6 } & Shell Width $(\mathrm{mm})$ & 360 & $39.95 \pm 4.20$ & 21.28 & 51.18 \\
\cline { 2 - 6 } & Shell Height $(\mathrm{mm})$ & 360 & $26.90 \pm 3.74$ & 13.37 & 36.23 \\
\cline { 2 - 6 } & Weight $(\mathrm{g})$ & 360 & $48.41 \pm 16.63$ & 6.69 & 124.15 \\
\hline
\end{tabular}

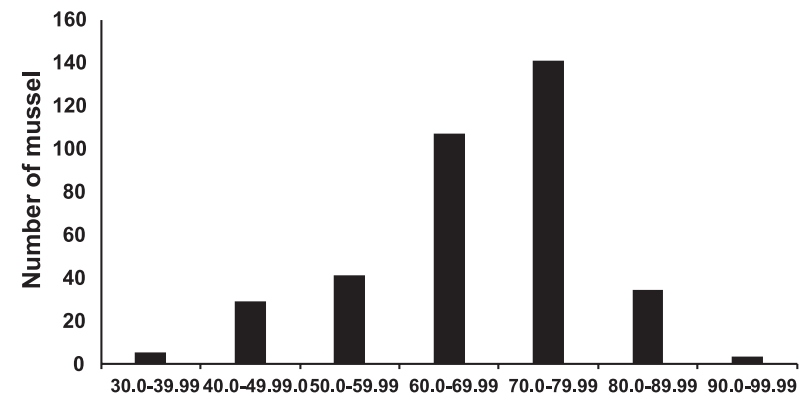

Fig. 4. Frequency distribution of $U$. crassus shell length.

\section{Discussion}

Freshwater mussel species are extremely important organisms for the conservation of freshwater ecological balance. The environmental factors are very important in the areas where these populations are distributed for sustainability of the species [17-18]. Although $U$. crassus is resistant to undesirable environmental conditions, the population of this species was reduced in many European countries and it became endangered $[10,19]$. Biological activities of $U$. crassus could be affected by factors such as water temperature, turbidity, or availability of nutrition, and at the same time, water acidity may be effective on shell growth [18, 20-21]. During the study period, U.crassus was distributed between 9.8 and $24^{\circ} \mathrm{C}$ temperature in Çine Creek, therefore this species can live commonly in such temperature ranges. There is a positive effect of water temperature on the body growth rate [10], while water temperature is one of the most important factors in releasing the glochidia larvae [21], thus it affects reproduction and the condition of the population in the environment [22-24].

The dissolved oxygen level, $\mathrm{pH}$, and water temperatures were highly correlated among themselves [25-26]. U. crassus individuals need high dissolved oxygen levels, so the oxygen value of the environment is very important [27]. While the oxygen level in Çine Creek ranged from 6-10.4 mg/L, the oxygen level was reported to be between $8-11 \mathrm{mg} / \mathrm{L}$ in Lužnice River (Czech Republic) where U. crassus was distributed [27], and in Malopolska (Poland) it ranged between 10.0 and $11.3 \mathrm{mg} / \mathrm{L}$ [28]. When the negative effects of a low amount of oxygen on $U$. crassus are examined, it is noteworthy that this species is not found in still water, especially where the change in oxygen content is more important [27]. The oxygen level in Çine Creek was

Table 2. Relationships of biometrical measurements on U.crassus.

\begin{tabular}{|c|c|c|c|c|}
\hline & $\mathrm{N}$ & Equation & Correlation Coefficient (r) & Growth Type \\
\hline Shell length-Weight & 360 & $\mathrm{~W}=0,0002 \mathrm{~L}^{2,8874}$ & 0.97 & Allometric (-) \\
\hline Shell length-Shell height & 360 & $\mathrm{~W}=0,4120 \mathrm{~L}^{0,9759}$ & 0.94 & Allometric (-) \\
\hline Shell length-Shell width & 360 & $\mathrm{~W}=0,7278 \mathrm{~L}^{0,9369}$ & 0.96 & Allometric (-) \\
\hline Shell height -Shell width & 360 & $\mathrm{~W}=0,6675 \mathrm{~L}^{0,9997}$ & 0.93 & Allometric (-) \\
\hline Shell height -Weight & 360 & $\mathrm{~W}=0,0051 \mathrm{~L}^{2,7752}$ & 0.96 & Allometric (-) \\
\hline Shell width -Weight & 360 & $\mathrm{~W}=0,0008 \mathrm{~L}^{2,9785}$ & 0.97 & Allometric (-) \\
\hline
\end{tabular}


determined at $6 \mathrm{mg} / \mathrm{L}$ only in August, but it is thought that this value is not adversely affected since water is not still in observations made in this environment.

In this study, it was determined that the level of nutrition was high in Çine Creek during the year. The amount of TPM is high when the amount of chlorophyll is low, and the amount of chlorophyll is high when the amount of TPM is low. Hochwald [10] reported that even if the temperature is low, as long as the nutrients are abundant in the areas where $U$. crassus is distributed, the metabolism slows down and the growth continues with a low pace, thus these individuals live long and spawn many times. In our study area it is thought that even if the temperature decreases, the process of feed intake continues at a slow pace. Douda [27] reported that the U.crassus individuals in Luznice and Nezarka Rivers show very rapid growth and short life spans, and that the metabolic rates of these individuals are high. This suggests that metabolic changes of $U$. crassus populations in different regions may be different according to environmental conditions.

The shell measurements and population dynamics of $U$. crassus are related to the water conditions and the region [10, 29-30]. In studies on $U$. crassus, the maximum shell length was reported as $66.9 \mathrm{~mm}$ in the Wkra River (Poland) [31]), $67.4 \mathrm{~mm}$ in the Palakaria River (Bulgaria) [32], $81 \mathrm{~mm}$ in Bohemia (Czech Republic) [30], $83 \mathrm{~mm}$ in Estonia [9], $85.4 \mathrm{~mm}$ in the Vantaa River (Finland) [33], and $95 \mathrm{~mm}$ in the Susa River (Denmark) [34]. During this study, which was done in Çine Creek, the largest length was measured as $92.50 \mathrm{~mm}$, while another study conducted in Sapanca Lake on the west coast of Turkey reported that $U$. crassus were found with lengths of $74 \mathrm{~mm}$ [35]. When all these studies are taken into consideration, it is seen that the mussel measured in Çine Creek has the longest length except for the Susa River. Helama et al. [33] reported that the average age of death for $U$. crassus individuals in the Vantana River (Finland) was 12.5 years and the longest living individual has a lifespan of 38 years, and that these individuals weighed $58.7 \mathrm{~mm}$ on average and weighed $14.9 \mathrm{~g}$ on average. The largest individual measured $85.4 \mathrm{~mm}$ and weighed $44.4 \mathrm{~g}$ and this individual was 15 years old. It is estimated that the major part of the population in Çine Creek is over 15 years old, as most individuals distributed in Çine Creek are larger than the individuals in the Vantana River [33]. This shows that the $U$. crassus species in this region can live for a long time. On the other hand, Nagel et al. [36] indicated that there was a large degree of plasticity in growth, for example individuals measuring $40 \mathrm{~mm}$ may be between 2 and 14 years old.

It is difficult to find juvenile individuals due to the fact that $U$. crassus species live completely buried in substratum [10]. In this study, the smallest size among the individuals taken from Çine Creek was measured as $37.03 \mathrm{~mm}$. Lamand and Beisel [37] reported that juveniles of $U$. crassus were only observed during sediment excavation and sieving. In total, 36 juveniles (length $<30 \mathrm{~mm}$ ) were found in five rivers in France and the smallest individual $(12 \mathrm{~mm})$ was measured in the Esch River. Douda [27] reported that the smallest group of $U$. crassus was $5-10 \mathrm{~mm}$ in his work about the Luznive River. Differences between the sampling methods of these two studies and the method of manual collection in Çine Creek have reduced the possibility of obtaining smaller juveniles. In addition, Douda [27] found that the most frequent group in the Luznive River was the 50-55 mm length group, whereas in our study the most frequent group was the 70.0-79.99 mm length group. This shows that $U$. crassus individuals in this region may have had more reproductive seasons.

The relationship between absolute and relative shell growth is very important due to the use of shape indexes in shellfish systematics. The form of a shell, described by shape indexes, is one of the taxonomic characters used both in describing the species and in taxonomic diagnostics of individuals [38]. There was a negative allometric relationship in all biometric measurements in Çine Creek. Besides, a strong correlation was found between these measures. Rizhinashvili [38] reported that both negative allometry and positive allometry were detected in biometric measurements in the Valdai water system and the Plyussa River (Russia). While the coefficient b is evaluated as 1 in the study of Rizhinashvili [38], in our study, the calculation is made according to 3 , therefore the negative/positive differences found in allometry are due to the coefficient.

\section{Conclusions}

Freshwater mussel $U$. crassus species is listed among endangered species in many parts of Europe. There is not enough data about the status of this species in Turkey. With this study, it was determined that juvenile and mature individuals of $U$. crassus exist in Çine Creek, and the presence of individuals in various length groups indicates that the life cycle for this species is being completed under the present environmental conditions in this region. Undoubtedly, the histological studies that will be carried out should reveal the gonad developmental stages and the time of reproduction in this region. In addition, it is necessary to allow more species to reproduce and grow larvae in sheltered areas that can be formed in Çine Creek and also to allow the growth of the larvae of glochidia, the host fishes should be protected. After the detailed population studies are done, Çine Creek can be determined as a potential stock region for producing species of $U$. crassus manually and to transplant offspring to areas that have low population by providing optimal conditions. 


\section{Acknowledgements}

This study was partly supported by the Scientific and Technological Research Council of Turkey under the University Student Scholarship Program. The authors would like to thank Ünsal Orhan for help in field observations.

\section{Conflict of Interest}

The authors declare no conflict of interest.

\section{References}

1. VAUGHN C.C. Ecosystem services provided by freshwater mussels. Hydrobiologia, 810 (1), 15, 2018.

2. BHUIYAN M.M.S., RAHMAN M.R., JAHAN M.S., HAQUE M. New Record of Some Freshwater Mussels (Bivalvia: Unionidae) From North-East Bangladesh. Bangladesh J. Zool. 41 (1), 29, 2013.

3. SICURO B. Freshwater bivalves rearing: a brief overview. Int. Aquat. Res. 7, 93, 2015.

4. LOPES-LIMA M., TEIXEIRA A., FROUFE E., LOPES A., VARANDAS S., SOUSA R. Biology and conservation of freshwater bivalves: past, present and future perspectives. Hydrobiologia, 735, 1, 2014.

5. ZIERITZ A., GUM B., KUEHN, R., GEIST J. Identifying freshwater mussels (Unionoida) and parasitic glochidia larvae from host fish gills: a molecular key to the North and Central European species. Ecology \& Evolution 2, 740, 2012.

6. TAEUBERT J.E., GUM B., GEIST J. Host-specificity of the endangered thickshelled river mussel (Unio crassus, Philipsson 1788) and implications for conservation. Aquat. Conserv.: Marine Freshw. Ecosyst. 22, 36, 2012.

7. DENIC M., STOECKL K., GUM B., GEIST J. Physicochemical assessment of Unio crassus habitat quality in a small upland stream and implications for conservation. Hydrobiologia 735, 111, 2014.

8. LOPES-LIMA M., KEBAPCI U., VAN DAMME D. Unio crassus. The IUCN Red List of Threatened Species 2014: e.T22736A42465628. http://dx.doi.org/10.2305/IUCN. UK.2014-1.RLTS.T22736A42465628.en, 2014.

9. TIMM H., MUTVEI H. Shell growth of the freshwater unionid Unio crassus from Estonian rivers. Proceedings of the Estonian Academy of Sciences, Biology 42, 55, 1993.

10. HOCHWALD, S. Plasticity of life-history traits in Unio crassus. Pages 127-141. In: G. Bauer and K. Wächtler (eds.). Ecology and evolution of the freshwater mussels Unionoida. Springer-Verlag, Berlin, 2001.

11. HAAG W.R., RYPEL A.L. Growth and longevity in freshwater mussels: evolutionary and conservation implications. Biological Reviews 86, 225, 2011.

12. YALÇIN M. Effect of Environmental Factors on Growth, Biochemical Parameters and Condition Index in Freshwater Mussel (Unio pictorum Linnaeus, 1758), Ondokuz May1s University, Institute of Science, MSc Thesis, Samsun, Turkey, 70, 2006.

13. ŞEREFLIŞAN H., GÖKÇE, M.A. Growth Performance of the Freshwater Mussel, Unio terminalis delicates (Lea, 1863) (Mollusca: Bivalvia: Unionidae) in the Gölbaşı Lake, Turkey. Pakistan J. Zool., 48 (4), 1109, 2016.
14. KAZANCI N., GÜRBÜZ A., BOYRAZ S. Geology and Evolution of the River Büyük Menderes, Western Anatolia, Turkey. Geological Bulletin of Turkey 54 (1-2), 2011.

15. STRICKLAND J.D.H., PARSONS T.R. A practical Handbook of Seawater Analysis. Fisheries Research Board of Canada, Bulletin 167. Ottawa. 310, 1972.

16. RICKER W.E. Computation and Interpre-tation of Biological Statistics of Fish Populations. Bulletin Fisheries Research Board of Canada, 191, 382, 1975.

17. RICHTER A., STOECKL K., DENIC M., GEIST J. Association between the occurrence of the Thick-shelled River Mussel (Unio crassus) and macroinvertebrate, microbial, and diatom communities. Freshwater Science 35, 922, 2016.

18. TAEUBERT J.E., EL-NOBI G., GEIST J. Effects of water temperature on the larval parasitic stage of the thickshelled river mussel (Unio crassus). Aquatic Conservation: Marine and Freshwater Ecosystems 24, 231, 2014.

19. STOECKL K., TAEUBERT J.E., GEIST J. Fish species composition and host fish density in streams of the thick-shelled river mussel (Unio crassus) - implications for conservation. Aquatic Conservation: Marine and Freshwater Ecosystems 25, 276, 2015.

20. STRAYER D.L. Understanding how nutrient cycles and freshwater mussels (Unionoida) affect one another. Hydrobiologia 735, 277, 2014.

21. SCHNEIDER L.D. Ecology of the threatened thick-shelled river mussel Unio crassus (Philipsson 1788) with focus on mussel-host interactions. Introductory papers in Biology, Karlstad University 27, 2014.

22. DOUDA K., HORKÝ P., BÍLÝ M. Host limitation of the thick-shelled river mussel: identifying the threats to declining affiliate species. Animal Conservation 15, 536, 2012.

23. GĄSIENICA-STASZECZEK M., ZAJĄC K., ZAJĄC T., OLEJNICZAK P. In vitro culture of glochidia of the threatened freshwater mussel Unio crassus Philipsson 1788 - the dilution problem, Invertebrate Reproduction \& Development, DOI: 10.1080/07924259.2017.1362482, 2017.

24. SCHNEIDER L.D., NILSSON P. A., ÖSTERLINGG E. M. Evaluating temperature- and host-dependent reproduction in the parasitic freshwater mussel Unio crassus. Hydrobiologia 810, 283, 2018.

25. CÉSAR II., MARTÍN SM., RUMI A., TASSARA M. Mollusks (Gastropoda and Bivalvia) of the MultipleUse Reserve Martín García Island, Río de la Plata River: biodiversity and ecology. Braz J Biol.; 72 (1), 121, 2012.

26. KALCHEV R., BESHKOVA M., BOTEV I., KALCHEVA H., KENDEROV L., KOZUHAROV D., TRICHKOVA T. Relation of Transparency, Dissolved Oxygen and $\mathrm{pH}$ to Dreissena spp. (Mollusca: Bivalvia) Occurrence in Bulgarian Standing Waters. Acta Zoologica Bulgarica 66 (3), 389, 2014.

27. DOUDA K. The occurrence and growth of Unio crassus (Mollusca: Bivalvia: Unionidae) in Lužnice River Basin in respect to water quality. Acta Universitatis CarolinaeEnvironmentalica 21, 57, 2007.

28. HUS M., ŚMIAŁEK M., ZAJĄC K., ZAJĄC T. Occurrence of Unio crassus (Bivalvia, Unionidae) depending on water chemistry in the foreland of the Polish Carpathians. Polish Journal of Environmental Studies, 15, 169, 2006.

29. ZAJAC K., ZAJAC T., C'MIEL A. What can we infer from the shell dimensions of the thick-shelled river mussel Unio crassus? Hydrobiologia 810, 415, 2018.

30. BONK M. Notes on the thick-shelled river mussel Unio crassus Philipsson, 1788 (Bivalvia: Unionidae) in 
Stradomka (southern Poland), a tributary of the Raba river. Folia Malacol. 24 (4), 289, 2016.

31. LEWIN I. Molluse communities of Lowland rivers and Oxbow lakes in agricultural areas with anthropogenically elevated nutrient concentrations. Folia Malacologica, 22 (2), 87, 2014

32. KENDEROV L., SASHOV Y. New Record of Thick Shelled River Mussel Unio crassus (Unionidae, Bivalvia) From Palakaria River, Bulgaria. Ecological Engineering and Environment Protection, IX, 96, 2017.

33. HELAMA S., VALOVIRTA I., NIELSEN J.K. Growth characteristics of the endangered thick-shelled river mussel (Unio crassus) near the northern limit of its natural range. Aquatic Conservation: Marine and Freshwater Ecosystems, 27, 476, 2017.

34. SCHNEIDER L.D., ZÜLSDORFF V. Current status of the thick-shelled river mussel Unio crassus in the River Suså. Technical report UC LIFE Denmark (LIFE15NAT/ DK/000948): Actions for improved conservation status of the thick-shelled river mussel (Unio crassus) in Denmark, 2017.

35. ERCAN E., GAYGUSUZ Ö., TARKAN A.S., REICHARD M., SMITH C. The ecology of freshwater bivalves in the Lake Sapanca Basin, Turkey. Turkish Journal of Zoology 37, 730, 2013

36. NAGEL K.O., DÜMPELMANN C., PFEIFFER M. Effective Growth Cessation in Adult Unio crassus Philipsson, 1788 (Bivalvia: Unionidae) From Germany. Folia Malacol. 23 (4), 309, 2015.

37. LAMAND F., BEISEL J.N. Comparison of visual observation and excavation to quantify density of the endangered bivalve Unio crassus in rivers of northeastern France. Knowledge and Management of Aquatic Ecosystems 413 (11), 7, 2014.

38. RIZHINASHVILI A. L. On the Relationships between Absolute and Allometric Shell Growth in Unionid Mussels (Bivalvia, Unionidae) from European Russia. Inland Water Biology, 1 (3), 241, 2008. 